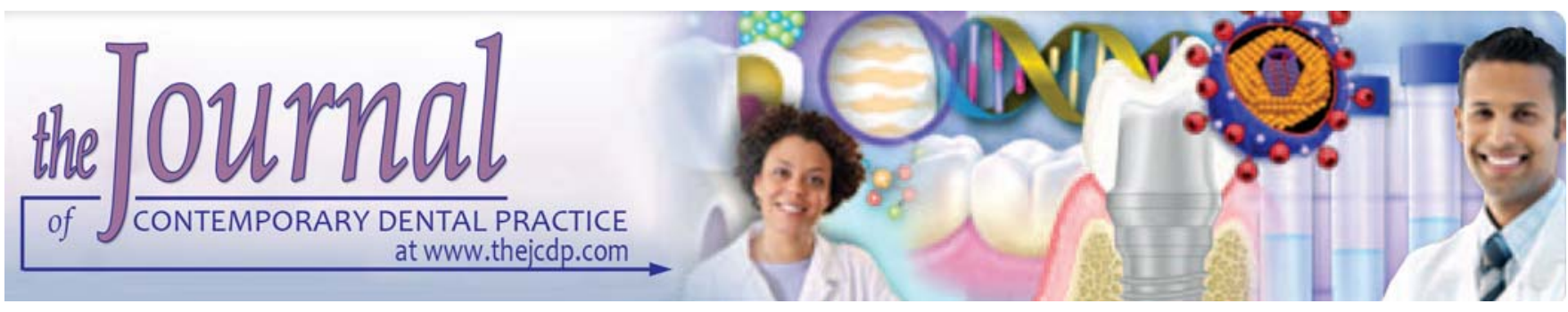

\title{
Awareness of Dental Surgeons in Pune and Mumbai, India, regarding Chemomechanical Caries Removal System
}

Mohammed Nadeem Ahmed Bijle, Shankargouda Patil, Shahzad S Mumkekar, Nitin Arora, Monika Bhalla, KV Murali

\begin{abstract}
Aim: To evaluate awareness of dental surgeons in Pune and Mumbai, India regarding chemomechanical caries removal system (CMCR).
\end{abstract}

Study design: Sixty practicing dental surgeons from Mumbai (30) and Pune (30) were surveyed using questionnaire.

Materials and methods: Qualitative data was collected on the basis of structured schedule questionnaire method.

Statistics: Statistical analysis was done using SPSS v. 12.0 To test statistical significance, $\mathrm{C}$ hi-square test, $\mathrm{F}$ ishers exact test and Mann-Whitney $\mathrm{U}$ test were used.

Results: Of total respondents, $46.7 \%$ dental surgeons in P une and $13.3 \%$ in Mumbai were aware about CMCR products. Carisolv ${ }^{\circledR}$ was known to $57.1 \%$ of dental surgeons in Pune and $75 \%$ in Mumbai, whereas, Papacarie ${ }^{\circledR}$ was known to $28.6 \%$ of dentists in Pune and none in Mumbai among the respondents aware about CMCR products.

Conclusion: A significantly higher proportion of dental surgeons from $P$ une were aware about CMCR products compared to Mumbai. Dental surgeons from Mumbai were unaware about Papacarie ${ }^{\circledR}$. Almost equal proportion of Dentists from Mumbai and $P$ une would like to undergo CDE programs to seek knowledge on CMCR, particularly Papacarie ${ }^{\circledR}$.

Keywords: Chemomechanical caries removal system (CMCR), Caridex, Carisolv ${ }^{\circledR}$, Papacarie $^{\circledR}$, Survey.

How to cite this article: Bijle MNA, Patil S, Mumkekar SS, Arora $N$, Bhalla M, Murali KV. Awareness of Dental Surgeons in P une and Mumbai, India, regarding $C$ hemomechanical Caries Removal System. J Contemp Dent Pract 2013;14(1):96-99.

Source of support: Nil

Conflict of interest: None declared

\section{INTRODUCTION}

One of the most common problems in clinical pediatric dentistry is how to minimize the use of drills to overcome fear and have a patient friendly approach. Chemomechanical caries removal system is one of the ideologies that have changed the perception of dental treatment, making it more patient friendly. This amounts to instill a positive dental attitude, which in turn reduces the efforts of pediatric dentist to imply behavior management techniques and achieve child's cooperation easily. On the other hand, pediatric Dentist's all around, have conceptualized the importance of preserving tooth tissue combined with a patient-friendly approach, which is becoming self-evident. This has led to revolutionize Dentistry with the concept of 'minimal invasive dentistry'. M inimal invasive dentistry comprises of various techniques, viz; air abrasion, atraumatic restorative technique, sono abrasion, laser and chemomechanical caries removal system (CMCR). ${ }^{1}$ Thus, CMCR can be designated as minimally invasive, painless and patient friendly technique, recommended for pediatric dental patients. ${ }^{1-6}$

Chemomechanical caries removal technique involves the application of chemical agents, to cause a selective softening of the carious dentine and facilitates removal by gentle excavation. Since, its inception in 1980's, CM CR has been originally marketed as 3 different systems, viz, Caridex, Carisolv ${ }^{\circledR}$ and Papacarie ${ }^{\circledR} .6,7$ Caridex required large volumes of solution and a special applicator tip, which weaned its popularity around 1990's and thus, was discontinued to be marketed. ${ }^{7}$ Carisolv ${ }^{\circledR}$ and Papacarie ${ }^{\circledR}$ were later introduced around 2000, which had overcome the limitations of Caridex and are being used among the clinicians aware of this technique.

Carisolv ${ }^{\circledR}$ (Fig. 1) system uses a gel and special instruments that removes the pathologically affected portion of the tooth structure and preserves the healthy tissue. Papacarie $^{\circledR}$ (Fig. 2) is based on a similar system as latter but does not include special instruments for caries removal 
Awareness of Dental Surgeons in Pune and Mumbai, India, regarding Chemomechanical Caries Removal System

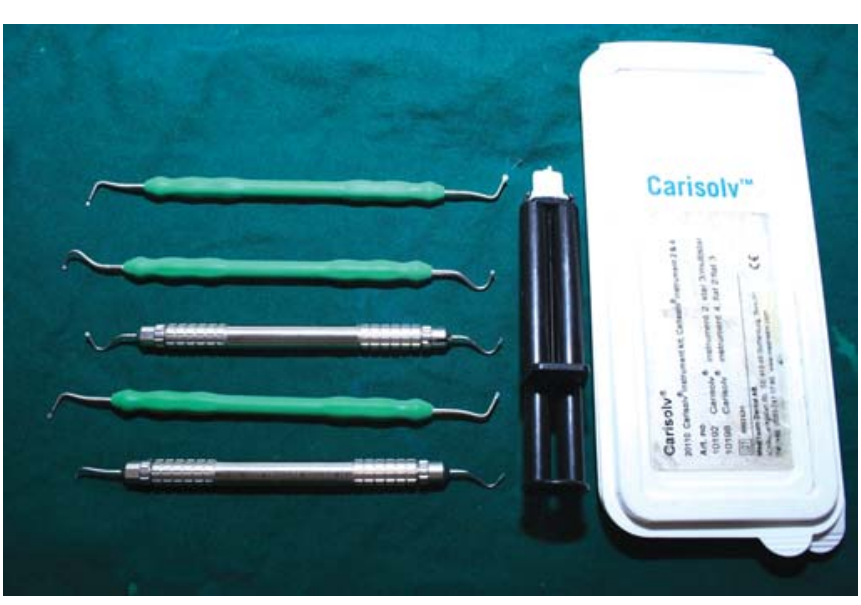

Fig. 1: Carisolv ${ }^{\circledR}$

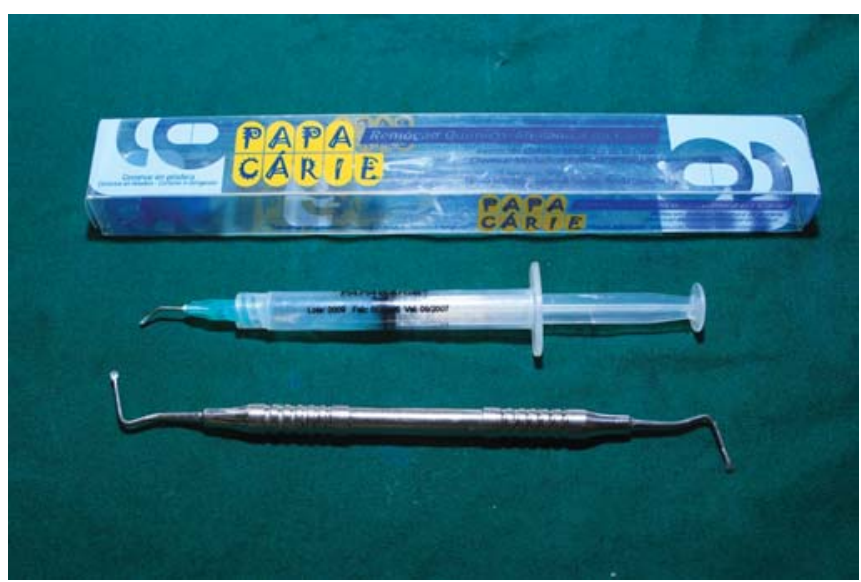

Fig. 2: Papacarie ${ }^{\circledR}$

and is relatively cheap. ${ }^{8} \mathrm{~B}$ oth systems have been proved to be effective in caries removal. ${ }^{9}$ However, high cost is a limiting factor to daily use in developing and underdeveloped countries. ${ }^{10}$

India is one of the developing countries. Since, the popularity of any system depends upon its economic viability, under-developed and developing countries find it difficult to incorporate an expensive mode of treatment. As mentioned previously, CMCR includes high cost, due to which its popularity in a developing country like India is nonjudgmental. A lthough an expensive mode of treatment, CM CR being an effective technique for pediatric and special children would be one of the reasons to incorporate into clinical pediatric dental practice.

Hence, this study was carried out to determine the awareness of CM CR among clinicians in M umbai and Pune, which if not present can be incorporated through continuing dental education programs and marketing.

\section{MATERIALS AND METHODS}

Qual itative approach was chosen to probe the awareness of dental surgeons in Pune and $M$ umbai, India regarding CMCR. This research was conducted by authors from
Department of Pedodontics and Preventive Dentistry, M A Rangoonwala College of Dental Sciences and Research Centre, Pune, M aharashtra, India.

Sixty practicing dental surgeons from M umbai (30) and Pune (30) were surveyed using questionnaire. Qualitative data was collected on the basis of structured schedule questionnaire method. The schedule comprised of the following questions:

1. General information viz, Name, Address, Contact information, etc.

2. Questions related to clinical practice viz, No. of years in clinical practice, flow of practice, frequency of patients with dentinal caries and treatment modality incorporated to deal with dentinal caries.

3. Questions related to $C M C R$ viz, familiarity and its length; product specification and type, grade, satisfaction, interest and recommendation, etc.

Clinicians responded to the schedule through a volunteer. A single volunteer was appointed to carry out survey in both the areas.

Q ual itative data recorded was then entered in M S Office, Excel Sheet 2007. Data entered was subjected to statistical analysis using SPSS v. 12.0. To test statistical significance, Chi-square test, Fishers exact test and $M$ ann-W hitney $\mathrm{U}$ test were used.

\section{RESULTS}

The age and sex distribution of respondent dentists was significantly different between two locations. On account of general Information, most of the practitioners surveyed were male, around 35 years old and indulged in clinical practice for 5 to 10 years (Table 1 ).

The distribution of clinical experience was significantly different between two locations. The participating dentists from Pune had significantly higher clinical experience compared to M umbai participants (Table 1).

Table 1: Distribution of general information

\begin{tabular}{lccc}
\hline Location & & & \\
\hline Parameters & Pune $(n=30)$ & Mumbai $(n=30)$ & $p$-value \\
\hline Age (years) & $32(26-43)$ & $36(26-69)$ & 0.011 \\
Sex & & & \\
Male & $23(76.7)$ & $15(50.0)$ & 0.032 \\
Female & $7(23.3)$ & $15(50.0)$ & - \\
Experience & $9(30.0)$ & $3(10.0)$ & 0.000 \\
$<5$ years & $12(40.0)$ & $27(90.0)$ & - \\
$5-10$ years & $9(30.0)$ & 0 & - \\
$>10$ years & &
\end{tabular}

$\S$ Values are median (minimum - maximum) whose p-values are obtained using Mann-Whitney $U$ test. The rest of the values are $n$ (\%) whose $\mathrm{p}$-values are obtained using $\mathrm{Chi}$-square test ( $\mathrm{F}$ isher's exact test) 
The majority of dentists from Pune and M umbai used conventional method (A ir Rotor) to remove dentinal caries. Of total respondents, $46.7 \%$ dental surgeons in Pune and $13.3 \%$ in Mumbai were aware about CMCR products (Table 2 and Graph 1).

$\begin{aligned} & \text { Table 2: Distribution of survey information regarding } \\
& \text { awareness of CMCR }\end{aligned}$
\begin{tabular}{lccr} 
Parameters & Pune $(n=30)$ & Mumbai $(n=30)$ & p-value \\
\hline $\begin{array}{l}\text { Method used for removal of dentinal caries } \\
\text { Air rotor }\end{array}$ & $30(100.0)$ & $30(100.0)$ & - \\
$\begin{array}{l}\text { Other } \\
\text { Know about CMCR }\end{array}$ & 0 & 0 & - \\
Yes & $14(46.7)$ & $4(13.3)$ & 0.010 \\
No & $16(53.3)$ & $26(86.7)$ & - \\
\hline
\end{tabular}

The values are $n(\%)$ whose $p$-values are obtained using Chi-square test ( $F$ isher's exact test).

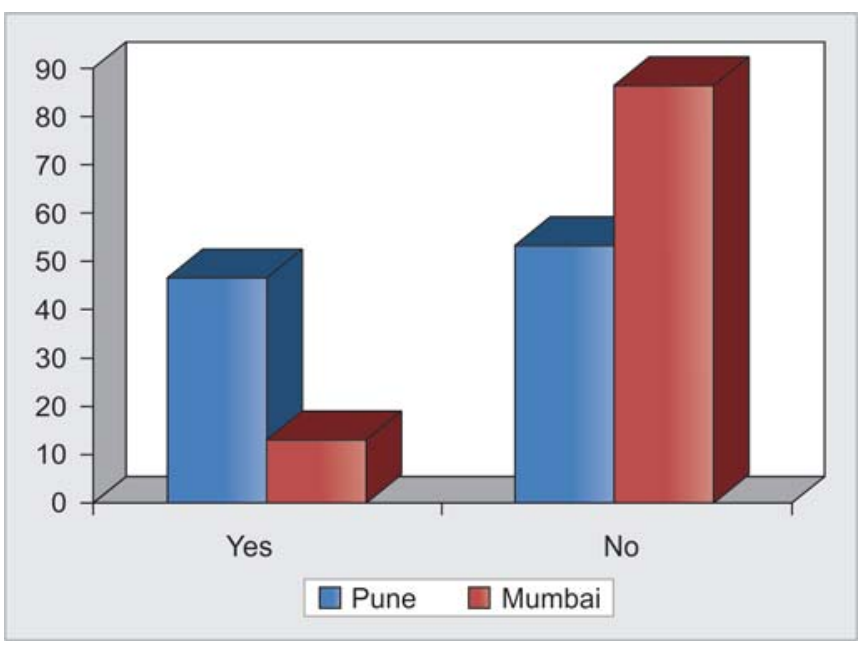

Graph 1: Distribution of awareness about CMCR

Caridex had an awareness among $14.3 \%$ of clinicians in Pune and $25 \%$ in M umbai, Carisolv ${ }^{\circledR}$ was known to $57.1 \%$ of dental surgeons in Pune and $75 \%$ in M umbai, whereas, Papacarie $^{\circledR}$ was known to $28.6 \%$ of dentists in Pune and none in $M$ umbai among the respondents aw are about CM CR products (Table 3 ). Although, $42.8 \%$ dental clinicians in Pune had an awareness of Papacarie ${ }^{\circledR}$ and Carisolv ${ }^{\circledR}$ both which was significant as compared to $\mathrm{M}$ umbai, where none were aware of both methods in combination (Table 3).

CM CR products known by dental clinicians in M umbai and Pune, were used by 28.6 and $25 \%$ respectively, rest did not have hands on experience till yet (Table 3 and Graph 2).

A pproximately equal proportion of dentist in M umbai (95.8\%) and Pune $(92.9 \%)$ were interested in CMCR products, in particular Papacarie ${ }^{\circledR}$ and would like to attend CDE program related to these products (Table 4).

\section{DISCUSSION}

A survey on the status of a CMCR carried out in USA and Canada, inferred noninclusion of CMCR in curriculum of

\begin{tabular}{|c|c|c|c|}
\hline Parameters & $\begin{array}{c}\text { Pune } \\
(n=14)\end{array}$ & $\begin{array}{c}\text { Mumbai } \\
(n=4)\end{array}$ & $\mathrm{p}$-value \\
\hline \multicolumn{4}{|c|}{ Awareness of CMCR products } \\
\hline Caridex & $2(14.3)$ & $1(25.0)$ & 0.030 \\
\hline Carisolv $^{\circledR}$ & $8(57.1)$ & $3(75.0)$ & - \\
\hline Papacarie ${ }^{\circledR}$ & $4(28.6)$ & 0 & - \\
\hline \multicolumn{4}{|c|}{ A wareness of CMCR products (combination) } \\
\hline Caridex and Carisolv ${ }^{\circledR}$ & $2(14.3)$ & 0 & 0.030 \\
\hline Carisolv $^{\circledR}$ and Papacarie ${ }^{\circledR}$ & $6(42.8)$ & 0 & - \\
\hline Caridex and Papacarie ${ }^{\circledR}$ & 0 & 0 & - \\
\hline All three & $2(14.3)$ & 0 & - \\
\hline \multicolumn{4}{|c|}{ Overall use of CMCR products } \\
\hline Yes & $4(28.6)$ & $1(25.0)$ & 0.878 \\
\hline No & $10(71.4)$ & $3(75.0)$ & - \\
\hline
\end{tabular}

The values are $n(\%)$ whose $p$-values are obtained using Chi-square test (Fisher's exact test)

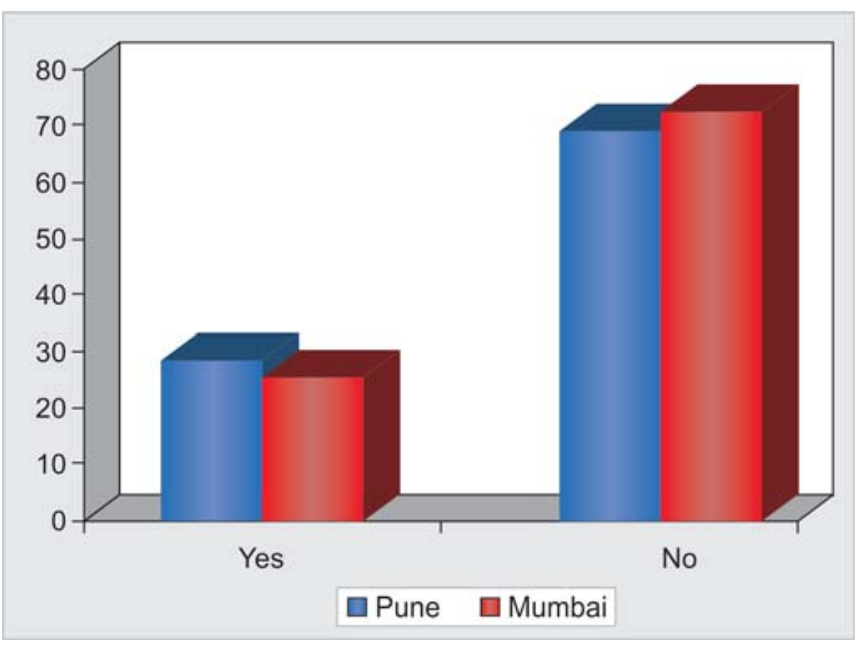

Graph 2: Distribution of use of CMCR products

Table 4: Distribution of survey information regarding CMCR product of interest and its respective CDE program for better understanding

\begin{tabular}{lccc}
\hline Parameters & Pune $(n=16)$ & Mumbai $(n=26)$ & p-value \\
\hline Interested in CDE programs for CMCR & & \\
Yes & $14(87.5)$ & $24(92.3)$ & 0.253 \\
No & $2(12.5)$ & $2(7.7)$ & - \\
CMCR product of interest & & \\
Carisolv $^{\circledR}$ & $1(7.1)$ & $1(4.2)$ & 0.315 \\
Papacarie $^{\circledR}$ & $13(92.9)$ & $23(95.8)$ & - \\
\hline
\end{tabular}

The values are $n(\%)$ whose $p$-values are obtained using $C$ hi-square test

dental schools with a significant difference of $88 \%$. Hence, majority of dentists graduating from dental schools in US and Canada were unaware about CMCR products. ${ }^{11}$ The results of latter mentioned survey ${ }^{11}$ seems to be similar with present survey, as the majority of dental surgeons in M umbai and Pune were unaware of CM CR products. A Ithough, the level of comparison cannot be standardized, as the present survey was carried out in 2010 and the previous survey ${ }^{11}$ was done in 1989; where CM CR products, i.e. Carisolv ${ }^{\circledR}$ 
Awareness of Dental Surgeons in Pune and Mumbai, India, regarding Chemomechanical Caries Removal System

and Papacarie ${ }^{\circledR}$ evaluated by present survey did not have existence. The difference of 21 years cannot be considered for comparison, as the development of minimal invasive dentistry has been remarkable in recent years throughout the globe.

Not many surveys have been carried in the subject of interest which provides limited scope for discussion as far as parameters are concerned. Although, some studies have proved, the use of CMCR finds no direct advantage as compared to traditional method for caries excavation in children. ${ }^{6,12}$ However, some authors support CM CR as acceptable method of dentinal caries excavation in children over conventional methods. ${ }^{5}$ Thus, usability and learn ability of CMCR products remains a debatable issue and should be left on individual dental surgeons choice.

\section{CONCLUSION}

A significantly higher proportion of dental surgeons from Pune were aware about CMCR products compared to $M$ umbai. Dental surgeons from Mumbai were unaware about Papacarie ${ }^{\circledR}$. A Imost equal proportion of Dentists from M umbai and Pune would like to undergo CDE programs to seek knowledge on CM CR, particularly Papacarie ${ }^{\circledR}$.

Furthermore, there is a need of a survey with increased respondents and on a national scale to conclude a definitive statement with evidence.

\section{CLINICAL SIGNIFICANCE}

CM CR products can be an al ternative supplemental method of dentinal caries removal, if known by dental clinicians for treatment of pediatric dental patients. Hence, appropriate knowledge and awareness of such products can be a valuable asset for dentists to incorporate in daily practice.

\section{REFERENCES}

1. Ganesh M, Dhaval P. Chemomechanical caries removal (CMCR) agents: Review and clinical application in primary teeth. J Dent Oral Hygiene $2013 \mathrm{M}$ arch;(3):34-45.

2. Kavvadia K, Karagianni V, Polychronopoul ou A, Papagiannouli L. Primary teeth caries removal using the Carisolv chemomechanical method: A clinical trial. Pediatr Dent 2004 Jan-Feb;26(1):23-28.

3. Munshi AK, Hegde AM, Shetty PK. Clinical evaluation of Carisolv in the chemicomechanical removal of carious dentin. J Clin Pediatr Dent 2001 Fall;26(1):49-54.

4. BalčiunienëI, Sabalaitë R, J uðkienël. Chemomechanical caries removal for children. Stomatologija, B altic Dent Maxillofac J 2005; 7:40-44.

5. Elkholany NR, A bdelaziz KM, Zaghloul NM, A boulenine N. Chemomechanical method: A valuable alternative for caries removal. J M inim Interv Dent 2009;2(4):248-59.
6. Inglehart M R, Peters M C, Flamenbaum M H, Eboda N N, Feigal RJ. Chemomechanical caries removal in children: A n operator's and pediatric patients' responses. J A m Dent Assoc 2007 J an; 138(1):47-55.

7. Beeley JA, Y ip HK, Stevenson A G. Chemochemical caries removal: A review of the techniques and latest developments. Br Dent J 2000 A pr 22;188(8):427-30.

8. Bussadori SK, Castro LC, Galvão AC. Papain gel: A new chemo-mechanical caries removal agent. J Clin Pediatr Dent 2005 W inter;30(2):115-19.

9. Corrêa FN, Rocha R de O, Rodrigues Filho LE, M uench $A$, Rodrigues $C R$. Chemical versus conventional caries removal techniques in primary teeth: A microhardness study. J Clin Pediatr D ent 2007 Spring;31(3):187-92.

10. Corrêa FN, Rocha RO, Soares FZ, Rodrigues-Filho $L E, R$ odrigues $C R$. Fluorescence of primary dentine after chemomechanical and conventional rotary excavation. Eur A rch Paediatr D ent 2008 Sep;9(3):126-29.

11. Scrabeck J G, L ist GM. The status of a chemomechanical caries removal system in dental education. Oper Dent 1989 Winter; 14(1):8-11.

12. Peters M C, Flamenbaum M H, Eboda N N, Feigal RJ, Inglehart $M$ R. C hemomechanical caries removal in children: Efficacy and efficiency. J Am Dent A ssoc 2006 Dec;137(12):1658-66.

\section{ABOUT THE AUTHORS}

\section{Mohammed Nadeem Ahmed Bijle (Corresponding Author)}

Lecturer, D epartment of Pedodontics and Preventive D entistry, $Y$ ogita Dental College and Hospital, K hed, Ratnagiri, Maharashtra, India e-mail: nbijle@yahoo.co.in

\section{Shankargouda Patil}

Senior Lecturer, Department of Oral and M axillofacial Pathology KLE College of Dental Sciences, Bengaluru, Karnataka, India

\section{Shahzad S Mumkekar}

Intern, Department of Pedodontics and Preventive Dentistry, M A Rangoonwala College of Dental Sciences and R esearch Centre, Pune $M$ aharashtra, India

\section{Nitin Arora}

Reader, Department of Orthodontics, M aharaja Gangasingh Dental College and Research Centre, Shri Ganganagar, Rajasthan, India

\section{Monika Bhalla}

Reader, Department of Prosthodontics, M aharaja Gangasingh Dental College and Research Centre, Shri Ganganagar, Rajasthan, India

\section{KV Murali}

Professor and Head, Department of Endodontics and Conservative Dentistry, Institute of Dental Sciences, B hubaneswar, Odisha, India 